\title{
GuideAR: Aplikasi Berbasis Augmented Reality dan Global Positioning System Untuk Pengenalan Daya Tarik Wisata
}

\author{
I Wayan Wegha Nanda Kusuma ${ }^{1}$, I Gede Juliana Eka Putra ${ }^{2}$, dan Bagus Putu Wahyu Nirmala ${ }^{3}$ \\ Program Studi Teknik Informatika \\ , Sekolah Tinggi Manajemen Informatika dan Komputer (STMIK) Primakara \\ Denpasar, Indonesia \\ Email: weghanandakusuma@gmail.com ${ }^{1}$, gedejep@primakara.ac.id ${ }^{2}$, bagus.p.wahyu@gmail.com $^{3}$
}

\begin{abstract}
Abstrak-GuideAR adalah sebuah aplikasi pengenalan tempat wisata dengan menggunakan teknologi augmented reality, aplikasi ini dikembangkan dengan menggunakan metode Agile, yaitu sebuah metode pengembangan software yang memerlukan adaptasi cepat dan dapat mengalami perubahan secara berkala sehingga bisa metode ini berfokus terhadap kualitas produk yang dihasilkan daripada dokumentasi, negosiasi kontrak, dsb. Pengembangan aplikasi GuideAR menggunakan teknologi augmented reality dan global positioning system sebagai teknologi utama dimana aplikasi akan menampilkan setiap tempat wisata dengan marker di layer perangkat yang digunakanan. Dari penggunaan metode Agile ini didapatkan bahwa aplikasi yang dibuat perlu dilakukan beberapa iterasi agar hasil yang didapat lebih maksimal. Hasil pengujian aplikasi memberikan saran agar menambahkan lokasi-lokasi wisata yang lebih banyak ke depannya agar lebih banyak tempat wisata di daerah Tegallalang yang terekspos dan lebih dikenal.
\end{abstract}

Kata Kunci-Aplikasi GuideAR; Augmented Reality; Metode Agile; Kecamatan Tegallalang.

Abstract - GuideAR is a tourist spot recognition application using augmented reality technology, this application was developed using the Agile method, which is a software development method that requires rapid adaptation and can change periodically so that this method can focus on the quality of the product produced rather than documentation, contract negotiations, etc. GuideAR application development uses augmented reality technology and global positioning system as the main technology where the application will display each tourist spot with a marker on the device layer used. From the use of the Agile method, it was found that the application needed to do several iterations so that the results obtained were maximized. The application test results provide suggestions for adding more tourist locations in the future so that more tourist attractions in the Tegallalang area are exposed and better known.

Keywords-GuideAR Application; Augmented Reality; Agile Method; Tegallalang District.

\section{PENDAHULUAN}

Bali merupakan salah satu destinasi pariwisata paling terkenal yang ada di Indonesia. Daya tarik Bali sendiri bukan hanya dari keindahan alamnya saja tapi juga dari keberagaman budaya, adat dan istiadatnya, hal itulah yang membuat Bali menjadi salah satu tujuan favorit wisatawan, baik wisatawan lokal maupun wisatawan luar negeri.

Seiring dengan pesatnya perkembangan teknologi dan informasi, banyak wisatawan memilih untuk menjelajahi Bali 'sendiri' atau bisa dibilang tanpa menggunakan jasa guide atau pemandu wisata. Wisatawan ini biasanya disebut dengan free individual traveller (FIT) yang merupakan salah satu jenis tren dalam dunia wisata beberapa tahun belakangan ini. Hal ini dikarenakan oleh mudahnya akses informasi, lokasi dan detail tempat wisata yang dapat dikunjungi di Bali sehingga banyak wisatawan yang tidak menggunakan jasa pemandu wisata lagi.

Namun, beberapa waktu terakhir banyak berita viral yang kurang mengenakan untuk didengar yang disebabkan oleh para wisatawan yang tanpa didampingi pemandu ini contohnya seperti wisatawan asing yang naik dan berfoto di atas tugu pelinggih Pura seperti Padmasana, kemudian wisatawan yang melanggar norma dan etika di tempat suci. Menurut sumbersumber berita dari kasus sejenis ini, pelanggaran aturan tersebut disebabkan oleh beberapa alasan seperti, terbatasnya informasi yang jelas mengenai aturan di tempat wisata bersangkutan serta kurangnya penempatan rambu-rambu larangan, kemudian tempat wisata yang dikunjungi tersebut tempatnya terpencil dan jarang dikunjungi wisatawan sehingga belum banyaknya informasi yang tersedia, dan yang terakhir disebabkan oleh lalainya pengawasan dan himbauan dari pengelola tempat wisata itu sendiri.

Teknologi augmented reality juga telah digunakan sebagai media informasi lokasi kampus yang ada di Bali agar 


\section{KดRMAPคTI}

proses penampilan informasi lebih interaktif dan lebih menarik. [1] Sistem dalam aplikasi $A R$ ini bekerja dengan cara menganalisis objek-objek di dunia nyata secara real time kemudian menggabungkan objek maya dengan objek di dunia nyata yang berjalan secara interaktif di waktu nyata yang kemudian ditampilkan dengan menggunakan kamera dari smartphone tersebut, hal inilah salah satu kelebihan dari teknologi augemented reality.

Penggunaan teknologi augmented reality $(A R)$ pada penelitian ini sendiri digunakan dengan menampilkan lokasi, informasi dan detail tempat wisata dapat dilihat secara langsung dari tampilan kamera smartphone dan desain interaksi antarmuka (interface) aplikasi dibuat dengan kombinasi interaksi gerakan 3 dimensi agar penggunaan aplikasi lebih menarik dan penerapan teknologi augmented reality lebih terasa, dan nantinya diharapkan dapat membuat pengalaman berwisata para wisatawan menjadi lebih menarik, interaktif dan tanpa gangguan dari orang lain. Oleh karena itu, aplikasi GuideAR ini dibuat agar dapat membantu para wisatawan khususnya wisatawan tanpa pemandu agar dapat mengetahui lokasi, informasi dan tata krama mengenai tempat wisata yang sedang dikunjungi. Selain itu, dengan adanya aplikasi ini diharapkan dapat membantu pengelola tempat wisata untuk menyediakan informasi yang jelas di saat tidak ada pemandu wisata ataupun pengawas yang bertugas.

Tempat-Tempat wisata sebagai bentuk realisasi dari pariwisata kerakyatan tentu akan mengandalkan masyarakat sekitar dalam pengelolaannya. Terkait dengan transformasi pemasaran konvensional menjadi digital maka masyarakat desa membutuhkan sebuah sarana yang memungkinkan hal tersebut. Sarana ini berbentuk aplikasi yang menjembatani penyampaian informasi pemasaran secara digital. Adanya aplikasi yang memberdayakan teknologi digital enabler dalam rangka pemasaran desa wisata bertujuan akhir meningkatkan kunjungan wisatawan. Meningkatnya kunjungan ini dapat memberikan efek positif pada motivasi masyarakat lokal dan pemerintah daerah dalam mengembangan desa wisatanya. [2]

\section{LANDASAN TEORI}

\section{A. Landasan Teori}

\section{1) Kecamatan Tegallalang}

Kecamatan yang terletak di Kabupaten Gianyar, Provisi Bali dengan jumlah penduduk lebih dari 53.390 orang menurut data dari Badan Pusat Statistik Kabupaten Gianyar, merupakan salah satu kecamatan yang memiliki banyak daya tarik wisata seperti objek wisata Cekingan di Desa Tegallalang, taman safari gajah di Desa Taro, Pura Gunung Kawi di Desa Sebatu, dll. Selain itu, wisatawan yang berkunjung ke Kecamatan Tegallalang juga dapat menikmati pengalaman wisata lainnya seperti agrowisata kopi, cycling, swing, wisata spiritual dan masih banyak lagi. Kecamatan Tegallalang adalah salah satu produsen kerajinan terbesar di Bali, hal ini dapat dilihat dari banyaknya toko kerajinan yang berada di sepanjang jalan raya Tegallalang.

Adapun 10 tempat wisata yang akan digunakan dalam penelitian ini yaitu:

- $\quad$ Ceking Rice Terrace

- Pura Gunung Kawi Sebatu

- Alas Harum Bali

- Aloha Swing

- Manuaba Waterfall

- Pura Griya Sakti

- Bali Pulina

- Genah Melukat Sebatu

- Gembok Cinta

- I Made Ada Gallery

2) Sistem Informasi Geografis

Sistem Informasi Geografis (Geografis Information System / GIS) adalah sebuah system yang didesain untuk menangkap, menyimpan, memanipulasi, menganalisa, mengatur dan menampilkan seluruh jenis data geografis. [3]

Adapun beberapa komponen dari sebuah SIG yaitu perangkat lunak (software), perangkat keras (hardware), data geospatial dan pengguna (user).

Data geospatial (data spasial dan non spasial) adalah dua jenis data yang digunakan dalam sebuah SIG. Data spasial adalah data yang berkaitan dengan kondisi geografi misalnya jalan raya, tinggi dataran, letak wilayah atau bisa dibilang data yang dapat digambarkan, sedangkan data non spasial adalah data-data berupa teks atau angka, biasa disebut dengan atribut misalnya jumlah kepadatan penduduk, jumlah tempat wisata, dan lain-lain.

\section{3) Aplikasi Mobile}

Aplikasi merupakan sebuah perangkat lunak yang dibuat untuk membantu dan memenuhi kebutuhan berbagai aktivitas atau pekerjaan manusia, seperti dalam bidang keuangan, periklanan, kesehatan, game bahkan sosial media. Aplikasi mobile di sini diartikan sebagai aplikasi yang dijalankan pada perangkat mobile seperti smartphone/hp.

4) Teknologi Augmented Reality

Augemented Reality merupakan sebuah teknologi yang menggabungkan objek-objek dunia nyata dan maya di lingkungan maya/virtual, sebuah aplikasi augmented reality berjalan secara interaktif secara real time atau waktu nyata.

Teknologi AR ini dapat menampilkan benda-benda atau marker dalam bentuk 3D. Tujuan dari teknologi ini agar pengunjung tidak merasa bosan dengan tampilan aplikasi informasi seperti biasanya, Teknologi ini pun sangat mudah digunakan yaitu dengan memanfaatkan kamera smartphone. [4] 


\section{KคRMดPดTI}

Adapun beberapa karakteristik augmented reality adalah sebagai berikut:

- Menggabungkan objek atau lingkungan di dunia nyata dan maya dengan grafis komputer.

- Melakukan pelacakan dan analisa lingkungan secara real time.

- Terdapat integrasi lingkungan dunia nyata dengan objek 3 dimensi.

- User dapat melakukan interaksi dengan objek maya (3d) pada aplikasi secara real time. [5]

\section{5) Xcode IDE}

Xcode adalah sebuah IDE (integrated development environment) atau platform gratis yang dibuat dan dikembangkan oleh Apple, platform pengembang aplikasi ini yang hanya dapat dijalankan pada sistem operasi macOS. Xcode memiliki berbagai alat-alat yang didapat digunakan untuk membuat/mengembangkan perangkat lunak atau aplikasi yang kemudian dapat dijalankan pada sistem operasi macOS, iOS, iPadOS, watchOS, dan tvOS (semua sistem operasi buatan Apple).

\section{6) Bahasa Pemrograman Swift}

Swift adalah bahasa pemrograman open source yang dibuat dan dikembangkan oleh Apple yang dapat digunakan pada Xcode untuk membuat/ mengembangkan software aplikasi untuk semua platform buatan Apple dan sistem berbasis Linux. Swift juga sangat mendukung pengembangan aplikasi augmented reality karena terintegrasi dengan platform ARKit milik Apple.

\section{7) Sistem Operasi iOS}

IOS adalah sistem operasi mobile yang dibuat dan dikembangkan oleh perusahaan teknologi asal Amerika Serika yaitu Apple. Sistem operasi ini hanya dapat berjalan di perangkat eksklusif yang dibuat oleh Apple juga yaitu IPhone dan IPod. Sistem operasi iOS juga sangat mendukung pengembang aplikasi-aplikasi augmented reality, hal ini dibuktikan dengan dirilisnya iOS 13 yang memiliki dukungan maksimal dengan teknologi augmented reality terbaru.

8) Sketch

Sketch adalah sebuah aplikasi yang sering digunakan untuk mendesain tampilan sebuah program/aplikasi. Sketch digunakan pada tahap desain aplikasi sehingga developer mendapatkan gambaran mengenai tampilan dari aplikasi yang akan dibuat.

\section{9) Apple ARKit}

ARKit adalah sebuah library pengembangan aplikasi augmented reality yang dibuat oleh Apple yang mana aplikasi yang dibuat dapat dijalankan perangkat iOS. ARKit 1 pertama kali diperkenalkan dengan iOS 11 dan perangkat yang bisa menjalankan ARKit ini minimal harus memiliki prosesor Apple
A9 (IPhone 6s) dan sampai saat penelitian ini dibuat iOS telah sampai versi 13 dan ARKit telah mencapai versi ARKit 3.

ARKit menggunakan kamera perangkat iOS akselerometer, giroskop, dan pengenalan lingkungan sekitar sebagai cara untuk pemetaan lingkungan sekitar saat perangkat yang digunakan, cara ini juga digunakan agar objek-objek maya 3 dimensi yang dimasukkan ke dalam aplikasi dapat diam atau berada di tempat yang telah ditentukan sebelumnya oleh pengembang aplikasi sehingga menghasilkan ilusi bahwa objek maya 3 dimensi tersebut benar-benar nyata.

10) MapKit

MapKit adalah sebuah library pemetaan atau maps pengembangan aplikasi augmented reality yang dibuat oleh Apple yang mana aplikasi yang dibuat dapat dijalankan pada perangkat iOS. MapKit memungkinkan pengembang aplikasi untuk mendapatkan akses lokasi/koordinat perangkat, akses data Apple Maps, dll. Sehingga MapKit dapat digunakan untuk pembuatan aplikasi berbasis lokasi untuk perangkat keras milik Apple.

\section{B. Tinjuan Pustaka (State of the Art)}

Dari penelitian Firdhaus Hari S A H dan Ovy Diansari Hendrati (2018), aplikasi yang dibuat adalah pengenalan landmark kota Surakarta dalam bentuk media pengenalan interaktif yang menampilkan objek 3 dimensi. Pada penelitian ini data didapat dari observasi, studi pustaka dan dokumentasi. Hasil pengujian menggunakan metode blackbox dalam hal pengujian fungsional oleh 20 tester dan $85 \%$ menyatakan baik dan sangat baik.[6]

Menurut T.M. Zaini dan OssyDwi Endah yang berjudul "Promosi Objek Wisata Unggulan Lampung Melalui Media "Magicbook" Berteknologi Augmented Reality", Aplikasi ini menggunakan marker sebagai alat tracking untuk menampilkan objek 3d pada buku AR yang dibuat. Hasil dari penelitian ini $80 \%$ responden dari kuesioner menjawab bahwa aplikasi sangat membantu media informasi tambahan untuk memberikan informasi yang lebih lengkap dan jelas terhadap objek yang wisata unggulan di Provinsi Lampung.[7]

Dari penelitian yang dilakukan oleh Indra Permana, Oky Dwi Nurhayati dan Kurniawan Teguh Martono yang berjudul "Location Based Service Sebagai Penunjuk Lokasi Hotel di Kota Semarang Berbasis Augmented Reality", Smartel adalah nama aplikasi mengenai sistem informasi lokasi mengenai hotel yang ada kota Semarang. Hasil dari percobaan aplikasi telah memenuhi kriteria seperti memudahkan pengguna dalam pencarian lokasi hotel, interaktif dalam menunjukkan lokasi hotel, penggunaannya mudah, dan informasi hotel ditampilkan dengan baik.[8] 


\section{KคRMAPคTI}

Dari penelitian yang berjudul "Metode Markerless Untuk Membangun Aplikasi Pemandu Wisata Wilayah Ciayumajakuning Berbasis Mobile Android" yang dilakukan oleh Selvia Lorena Br Ginting, Meylly Pamungkas dan Yogie Rinaldy Ginting. Aplikasi berbasis android ini digunakan sebagai alat untuk memandu wisatawan yang ber-kunjung ke daerah Ciayumajakuning dengan menampilkan lokasi dan informasi detail objek wisata. Hasil dari penelitian ini adalah penerapan teknologi markerless augmented reality dapat digunakan sebagai penanda keberadaan POI (point of interest) sesuai dengan posisi sebenarnya.[9]

Menurut penelitian Julia PurnamaSari dan Ernawati Aan Erlansari yang berjudul "Rancang Bangun Aplikasi Layanan Berbasis Lokasi Dengan Penerapan Augmented Reality Menggunakan Metode Markerless Berbasis Android (Studi Kasus: Pencarian Perangkat Daerah Kota Bengkulu)". Penerapan Augmented Reality menggunakan metode markerless yang dapat digunakan untuk pencarian lokasi perangkat daerah Kota Bengkulu dan karena aplikasi ini juga telah terintegrasi dengan GoogleMaps, user bisa langsung mencari rute menuju lokasi yang diinginkan. Hasil uji coba ke pengguna menunjukkan bahwa rata-rata $84 \%$ memberikan respon positif.[10]

Dari penelitian yang berjudul "Rancang Bangun Aplikasi Informasi Universitas Bengkulu Sebagai Panduan Pengenalan Kampus Menggunakan Metode Markerless Augmented Reality Berbasis Android" yang dilakukan oleh Abdur Rahman, Ernawati dan Funny Farady Coastera. Aplikasi yang dikembangakan menggunakan metode markerless dan pemanfaatan GPS sebagai cara untuk menampilkan lokasi dari setiap. Aplikasi panduan pengenalan kampus Universitas Bengkulu ini diujicoba pada OS Android Gingerbread 2.3, dengan masih uji coba medapatkan hasil sangat baik tampilan dan kualitas Userfriendly-nya.[11]

\section{METODOLOGI PENELITIAN}

Pada penelitian ini penulis menggunakan Metode Agile sebagai metodologi pengembangan aplikasi GuideAR ini. Metode Agile merupakan salah satu metode pengembangan software yang memerlukan adaptasi cepat dan dapat mengalami perubahan secara berkala sehingga metode ini berfokus terhadap kualitas produk yang dihasilkan daripada dokumentasi, negosiasi kontrak, dsb. [12]

Metode Agile lebih fleksibel dalam pembuatan sebuah sistem/aplikasi karena iterasi yang dilakukan tidak ada batasnya dan sistem/aplikasi yang dibuat secara bertahap yaitu dimulai dari pembuatan fitur utama yang kemudian dilanjutkan dengan fitur-fitur tambahan sehingga aplikasi/sistem yang dibuat dapat menyesuaikan dengan kebutuhan dan keinginan pengguna/user yang didapat dari umpan balik/feedback dari user pada versi aplikasi/sistem sebelumnya.

Adapun siklus-siklus pengembangan dengan metode Agile dapat dijelaskan sebagai berikut:

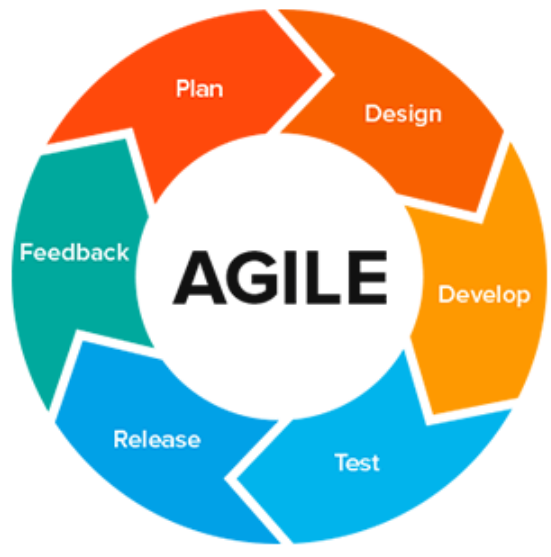

Gambar 1. Siklus Pengembangan Metode Agile

a) Perencanaan (Plan)

Seperti namanya pada proses perencanaan ini, penulis melakukan analisis fungsi dan mengumpulkan informasi serta kebutuhan-kebutuhan dari aplikasi yang akan dibuat.

b) Desain (Design)

Pada tahap desain ini penulis membuat rancangan dari aplikasi seperti rancangan sistem, rancangan tampilan dengan menggunakan aplikasi Sketch dan metode-metode programming mengenai pembuatan aplikasi augmented reality ini.

c) Pengembangan (Develop)

Dalam proses pengembangan ini penulis melakukan implementasi desain yang telah dibuat pada proses sebelumnya ke bentuk program. Pada tahap ini digunakan aplikasi Xcode dengan bahasa pemrograman Swift.

Berdasarkan beberapa tinjauan pustaka di atas, banyak yang menggunakan bahasa pemrograman Java sebagai bahasa untuk pengembangan aplikasi karena menggunakan sistem operasi Android. Swift dan Java sendiri adalah sama-sama bahasa pemrograman berorientasi objek sehingga cara pembuatan programnya akan mirip, selain itu Swift dipilih karena belum ada penelitian dengan topik augmented reality yang menggunakan bahasa pemrograman ini sehingga penelitian ini bisa dijadikan acuan khusus untuk penelitian sejenis yang akan menggunakan Swift sebagai bahasa dalam pengembangan program.

d) Uji Coba (Test)

Setelah aplikasi yang dibuat selesai/fungsi utama telah dibuat kemudian dilakukan proses uji coba, yaitu 


\section{KคRMดPดTI}

melibatkan periksaan aplikasi serta setiap bagian kode yang salah serta perbaikannya yang dimaksudkan untuk memperbaiki error atau bug di awal pengembangan agar aplikasi setidaknya dapat digunakan dengan lancar.

e) Rilis (Release)

Pada tahap ini aplikasi yang telah dibuat kemudian dirilis agar dapat dipakai oleh user yang lebih luas, dalam penelitian ini peneliti bisa merilis aplikasi melalui Apple Appstore. Selain itu, untuk mendapatkan hasil feedback lebih cepat penulis juga akan melakukan uji coba langsung ke wisatawan-wisatawan di sekitar daerah wisata Kecamatan Tegallalang.

f) Umpan balik (Feedback)

Setelah proses rilis, pengguna aplikasi GuideAR dapat memberikan masukan-masukan mengenai aplikasi ini agar dapat dilakukan perbaikan dan pembaharuan untuk fiturfitur pada aplikasi sehingga proses siklus metode Agile terus berputar hingga didapatkan aplikasi yang sesuai dengan keinginan user.

Berikut adalah gambaran awal diagram use case aplikasi GuideAR:

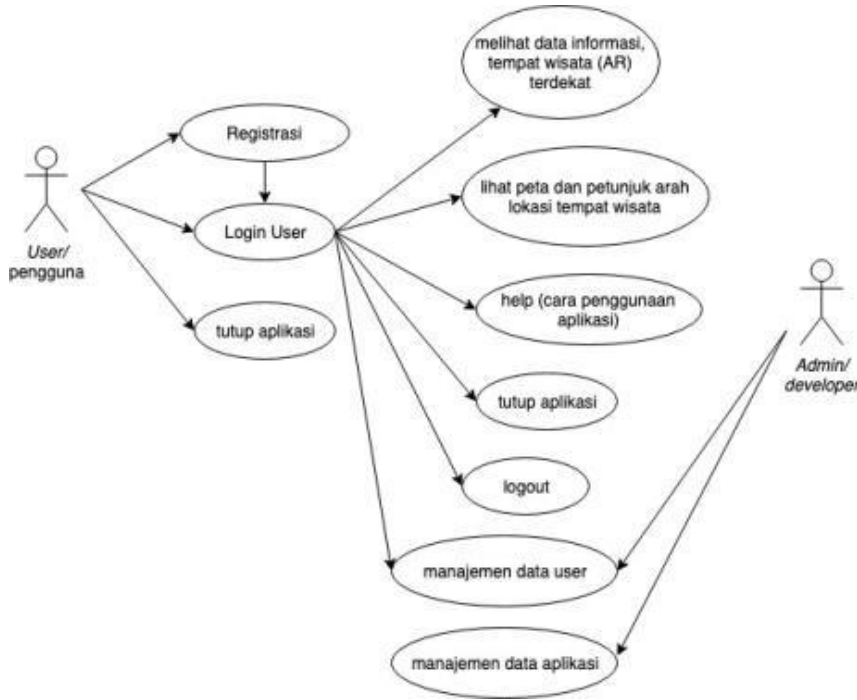

Gambar 2. Use Case Aplikasi

\section{PEMBAHASAN}

\section{A. Proses Rancang Bangun Aplikasi}

1) Perencanaan (Plan)

Pada tahapan ini penulis melakukan observasi di sekitar daerah Kecamatan Tegallalang untuk mencari tempat wisata yang akan dijadikan sebagai sampel konten aplikasi beserta detail-detail tempat tersebut, di sini deskripsi dalam aplikasi akan menggunakan bahasa Inggris sebagai deskripsi tempat wisata karena aplikasi ini ditujukan untuk user berbasis internasional.

Kemudian dilakukan perancangan kebutuhan sistem dan cara kerja aplikasi sesuai dengan use case diagram yang telah dibuat, adapun fungsi utama yang ingin dibuat dalam aplikasi ini yaitu mencangkup:

- Terdapat tampilan augmented reality marker lokasi tempat wisata dalam tampilan kamera.

- Terdapat tampilan peta yang menyesuaikan dengan lokasi pengguna.

- Terdapat anotasi di tampilan peta untuk setiap lokasi yang dapat diklik untuk melihat detail tempat tersebut.

- Ketika anotasi tersebut diklik, pengguna akan dipindahkan ke tampilan detail aplikasi yang mencangkup nama, foto, kategori, dan deskripsi dari lokasi tersebut.

- Dalam halaman detail lokasi tersebut terdapat tombol yang diklik yang akan memindahkan pengguna ke aplikasi Apple Maps untuk yang otomatis menunjukkan rute jalan/ directions menuju lokasi bersangkutan.

- Terakhir, terdapat halaman cara penggunaan aplikasi untuk membantu pengguna ketika memakai aplikasi.

2) Desain (Design)

Pada tahap desain aplikasi ini adalah proses pembuatan desain visual awal antar muka dari aplikasi yang dibuat dengan menggunakan aplikasi Sketch, desain tampilan aplikasi ini disesuaikan dengan kebutuhan sistem yang telah dibuat di atas. Dapat terjadi perbedaan dari hasil desain aplikasi dengan produk akhir mengingat pada proses pengembangan bisa terdapat perubahan karena alasan teknis.

Tahap awal desain aplikasi ini dimulai dengan pembuatan mockup, di mana desain dibuat difokuskan dalam penempatan setiap elemen desain dan tidak perlu menentukan warna ataupun teks dalam aplikasi.

Pada desain tampilan aplikasi ini dapat dilihat terdapat halaman splash screen, halaman utama yang memuat tampilan kamera dan tampilan peta yang didalamnya berisi anotasi setiap lokasi tempat wisata, selanjutnya terdapat tampilan detail lokasi yang berisi nama, foto, alamat, kategori, deskripsi, dan tombol directions. Halaman terakhir yaitu halaman petunjuk cara penggunaan aplikasi.

\section{3) Pengembangan (Development)}

Dalam proses pengembangan ini dilakukan implementasi dari desain yang telah dibuat pada proses sebelumnya ke dalam bentuk program aplikasi. 


\section{KดRMดPดTI}

1) Proses pengembangan dimulai dari pembuatan proyek baru di aplikasi Xcode dan menggunakan bahasa pemrograman Swift.

2) Kemudian dilanjutkan dengan pembuatan komponenkomponen aplikasi mulai dari fungsi tampilan kamera augmented reality, fungsi tampilan peta, anotasi lokasi, halaman cara penggunaan, halaman detail aplikasi, dan fungsi menentukan rute yang terhubung ke aplikasi Apple Maps.

3) Pada proses pengembangan ini juga dibuat Storyboard di mana akan memuat tampilan aplikasi yang akan diisi dengan code/program, pada Storyboard aplikasi ini menggunakan navigation controller yang fungsinya agar aplikasi yang dibuat dapat berpindahpindah beberapa halaman. Untuk aplikasi augmented reality, Xcode akan otomatis membuat ARSKView yang fungsinya adalah memuat fungsi tampilan augmented reality pada kamera perangkat.

4) Pada awal pengembangan aplikasi tidak ada tombol refresh pada tampilan utama kemudian pada iterasi kedua pengembangan ditambahkan tombol refresh yang fungsinya untuk me-reset GPS lokasi user pada aplikasi sehingga lokasi user yang terbaru dapat masuk dan lokasi tempat wisata pada tampilan kamera lebih akurat pada tampilan kamera.

5) Setelah semua komponen dan program utama aplikasi selesai dibuat dan tidak terdapat eror lagi, proses pengembangan aplikasi dilanjutkan ke dalam proses uji coba yang menggunakan metode blackbox.

\section{4) Uji Coba (Test)}

Pada tahap uji coba pertama aplikasi ini dilakukan dengan metode blackbox di mana pengujian difokuskan pada tampilan luar dan fungsional aplikasi tanpa mengetes kestabilan program yang dibuat.

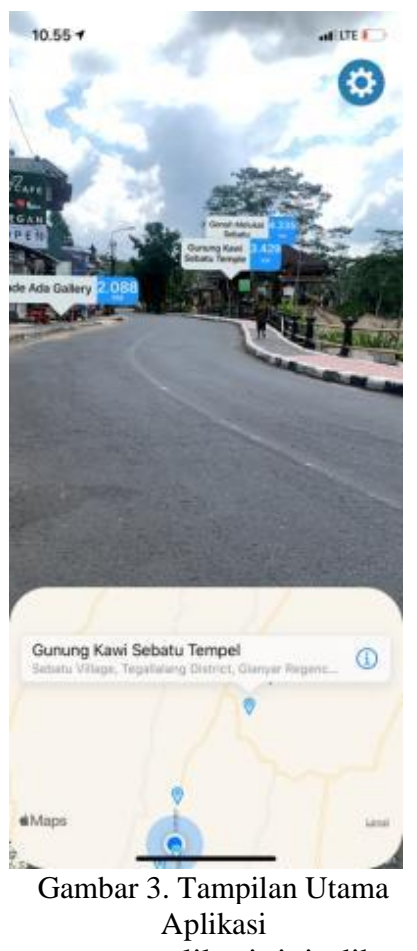

Tampilan utama aplikasi ini dibuat sesuai dengan desain aplikasi yang telah dibuat yaitu dengan memuat fungsi utama terdapat tampilan augmented reality kamera dengan anotasi lokasi secara realtime, dipojok atas kiri terdapat tombol halaman cara penggunaan aplikasi, dan di bagian bawah aplikasi terdapat tampilan peta lokasi yang menyesuaikan dengan tampilan lokasi pada kamera. Pada iterasi kedua pengembangan aplikasi ini ditambahkan tombol refresh yang berfungsi untuk meng-update lokasi GPS perangkat pengguna sehingga lokasi tempat wisata dan perangkat lebih akurat pada saat itu. 
e-ISSN: 2685-7006 | p-ISSN: $2252-9063$

Kumpulan Artikel Mahasiswa Pendidikan Teknik Informatika

(KARMAPATI)

Volume 10, Nomor 1, Tahun 2021

\section{KคRmดPดTI}

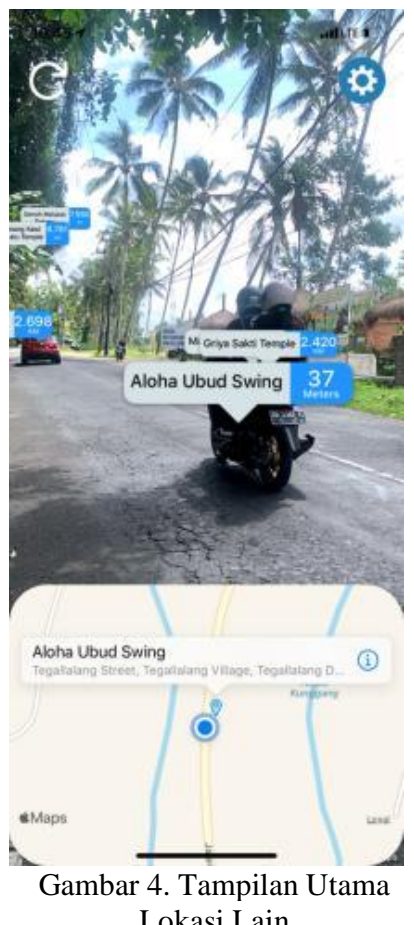

$$
\text { Lokasi Lain }
$$

Berikut adalah tampilan lain halaman utama yang berada di lokasi berbeda. Pada bagian peta anotasi lokasi dapat diklik dan akan menampilkan nama dan alamat tempat wisata kemudian di bagian kanan terdapat tombol yang ketika diklik akan membawa user ke halaman deskripsi lokasi tersebut.

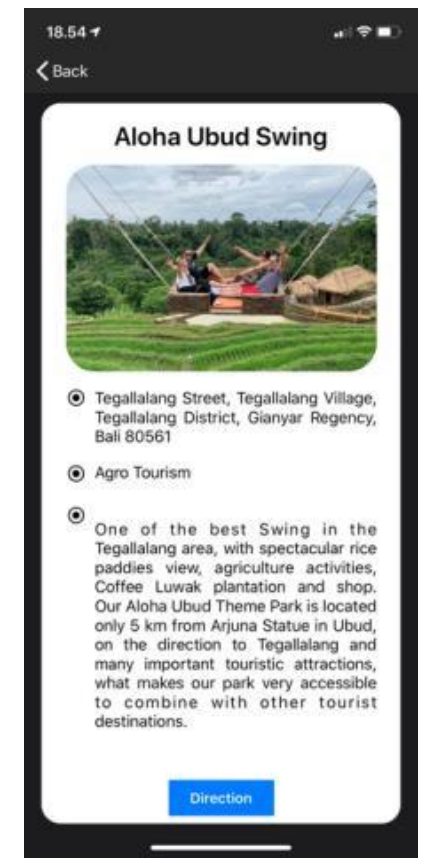

Gambar 5. Tampilan Detail Lokasi

\section{Tempat Wisata}

Tampilan detail lokasi tempat wisata di sini berisi nama, foto, alamat, kategori tempat dan deskripsi tempat tersebut. Di bawah keterangan tersebut akan terdapat tombol directions yang ketika diklik pengguna akan langsung dipindahkan ke aplikasi Apple Maps.

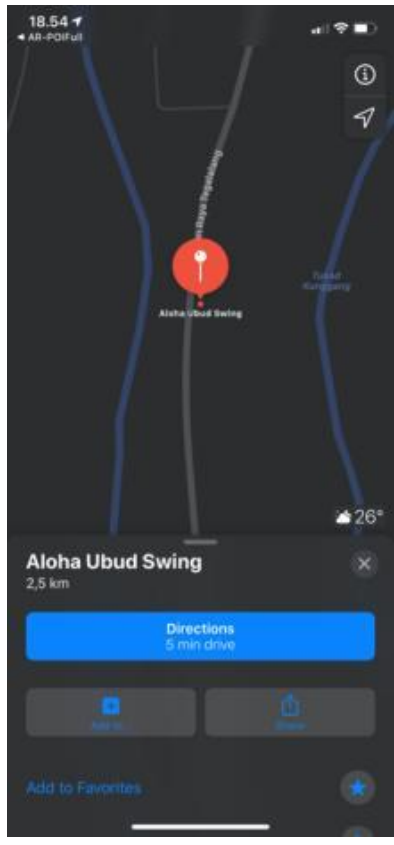

Gambar 6. Tampilan Aplikas Apple Maps Directions

Berikut adalah tampilan aplikasi Apple Maps ketika tombol directions pada halaman detail lokasi diklik, pada aplikasi Apple Maps lokasi tujuan pengguna akan langsung dimasukkan jadi pengguna tinggal klik tombol directions yang kemudian aplikasi akan langsung menentukan rute perjalanan. 


\section{KคRMดคดTI}

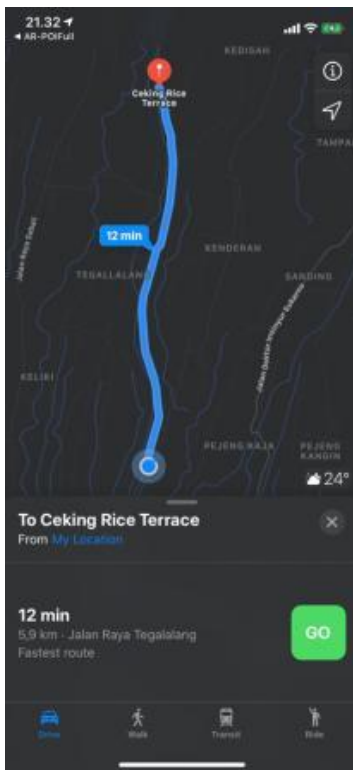

Gambar 7. Tampilan Rute ke Lokasi Ceking Rice Terrace

Gambar diatas adalah tampilan aplikasi ketika tombol "Directions" diklik, aplikasi akan otomatis menunjukan rute jalan menuju tempat yang dipilih.

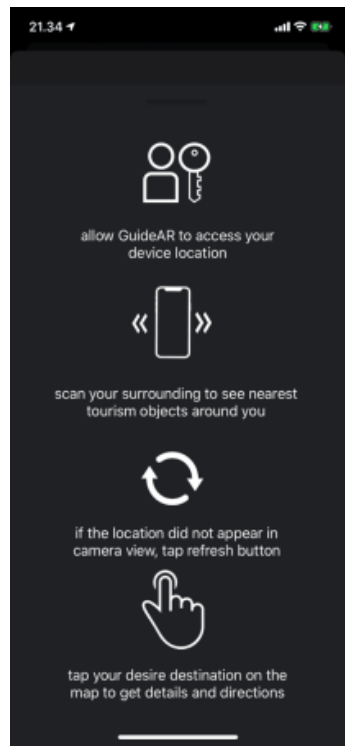

Gambar 8. Tampilan Cara

Penggunaan Aplikasi

Pada tampilan ini pengguna akan diberikan beberapa instruksi mengenai cara penggunaan aplikasi di antaranya yaitu, izinkan aplikasi untuk mengakses lokasi perangkat, instruksi arahkan perangkat ke sekitar anda agar dapat melihat lokasi terdekat, jika lokasi terdekat tidak tampil di kamera, coba klik tombol refresh agar me-reset lokasi GPS user yang akan membuat lokasi wisata terdekat dapat muncul pada tampilan kamera, kemudian yang terakhir terdapat instruksi untuk melihat detail dan rute lokasi dapat dilakukan dengan cara tap anotasi lokasi pada peta.

\section{5) Rilis (Release)}

Proses rilis pada aplikasi ini penulis batasi hanya dengan meng-install aplikasi pada perangkat IPhone yang akan digunakan sebagai perangkat uji coba aplikasi. Jika memang aplikasi yang dibuat akan digunakan untuk umum maka aplikasi harus dirilis/didistribusikan melalui App Store karena aplikasi yang dibuat berbasis sistem operasi IOS.

\section{6) Umpan balik (Feedback)}

Pada Tahap penerimaan umpan balik ini akan didapat setelah dilakukan uji coba dengan calon pengguna aplikasi, umpan balik ini pun sangat berguna karena saran dan kritikan tersebut dapat dijadikan sebagai acuan dan pengembangan fitur dalam iterasi pengembangan aplikasi ke depannya, adapun beberapa umpan balik/saran yang didapat ketika pengujian aplikasi GuideAR ini di antaranya yaitu:

1. Tambahkan lebih banyak lokasi tempat wisata di Tegallalang agar lokasi-lokasi tempat wisata yang tersembunyi lebih dikenal oleh wisatawan.

2. Pada saat uji coba terakhir beberapa pengguna juga memberi saran agar menambahkan foto yang lebih banyak untuk setiap lokasi.

\section{HASIL}

Pada pengujian implementasi penulis melakukan pengujian dengan cara wawancara dan uji penggunaan aplikasi dengan keluarga dan masyarakat yang berada di sekitar tempat wisata di daerah Tegallalang dengan jumlah 10 orang responden mengingat pengujian penelitian ini dilakukan ditengah masa pandemi dan lockdown sehingga jumlah responden yang didapatkan sangat sedikit dan tidak ada wisatawan asing yang mengunjungi tempat wisata terkait.

Adapun pertanyaan yang penulis ajukan yaitu.

1) Bagaimana menurut anda tampilan aplikasi GuideAR ini?

2) Apakah dengan adanya aplikasi GuideAR ini bisa membantu wisatawan dalam berwisata?

3) Jika aplikasi GuideAR ini dipublikasi apakah anda mau menggunakan aplikasi ini?

4) Apa saran atau tambahan fitur yang bisa anda berikan untuk aplikasi ini?

Dari proses wawancara dan pengujian langsung aplikasi GuideAR maka didapat beberapa kesimpulan yaitu:

1) Mayoritas penguji aplikasi menganggap tampilan aplikasi sudah bagus. 
e-ISSN: 2685-7006 | p-ISSN: $2252-9063$

Kumpulan Artikel Mahasiswa Pendidikan Teknik Informatika

(KARMAPATI)

Volume 10, Nomor 1, Tahun 2021

\section{KคRMAPคTI}

2) Aplikasi GuideAR ini dianggap dapat membantu para wisatawan dalam berwisata di daerah Tegallalang.

3) Penguji aplikasi juga ingin mengunduh aplikasi GuideAR atau aplikasi pemandu wisata sejenis jika mereka sedang berwisata ke daerah baru yang mereka kunjungi, karena aplikasi seperti ini dapat menjadi pemandu wisata dan menunjukkan tempat wisata terdekat di lokasi tersebut sehingga mereka tidak perlu bertanya lagi di masyarakat sekitar.

4) Pada proses pengujian ini beberapa penguji aplikasi mengharapkan agar ke depannya lokasi tempat wisata ditambah lagi ke depannya, misalnya konten aplikasi mencangkup daerah Ubud bahkan lebih luas lagi.

Hasil Revisi Aplikasi
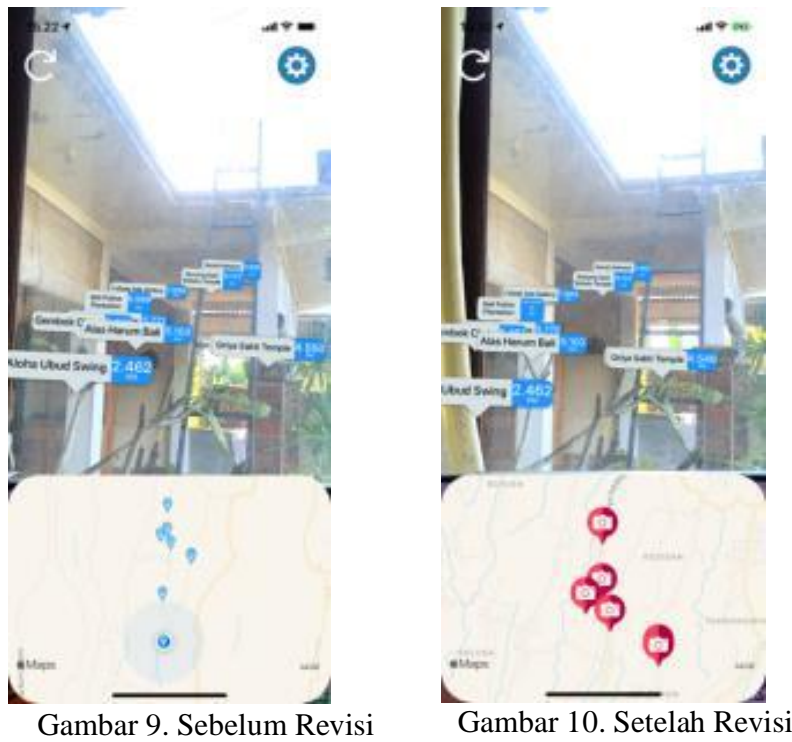

\section{PENUTUP}

\section{A. Kesimpulan}

Berdasarkan hasil dari pembahasan dan implementasi penelitian di atas dapat disimpulkan bahwa:

1) Metode Agile sangat efektif digunakan dalam proses pengembangan sebuah aplikasi atau perangkat lunak yang membutuhkan / memprioritaskan kecepatan perubahan sistem seperti mengubah sistem menu, menambah fitur sesuai dengan umpan balik yang didapat ketika proses pengujian aplikasi. Karena Metode Agile bersifat berputar/iterasi jadi proses pengembangan aplikasi dapat dilanjutkan terusmenerus sehingga produk yang dibuat mendapatkan hasil yang maksimal.
2) Hasil dari implementasi aplikasi GuideAR didapatkan bahwa kebanyakan pengguna telah puas dengan tampilan dan cara kerja aplikasi dan aplikasi ini diharapkan dapat membantu pengenalan pariwisata di daerah Tegallalang. Beberapa penguji aplikasi memberikan saran agar konten aplikasi nantinya dapat ditambah dan cakupan lokasinya dapat ditambah.

\section{B. Saran}

Penulis menyadari bahwa penelitian ini masih banyak terdapat kekurangan sehingga penelitian dengan metode dan topik sejenis masih bisa ditingkatkan lagi. Adapun beberapa saran yang dapat peneliti beri yaitu:

1) Pada aspek penelitian iterasi metode Agile sebaiknya dilakukan lebih banyak agar hasil dari aplikasi atau perangkat lunak yang dibuat lebih baik dan lebih maksimal.

2) Dalam proses pengujian aplikasi diusahakan agar mendapat responden yang lebih banyak lagi agar kritik dan saran yang didapat lebih beragam dan dapat menjadi acuan untuk pengembangan aplikasi menjadi lebih baik.

3) Dari aspek teknis, diharapkan dalam penelitian dengan topik augmented reality berbasis lokasi dapat menambahkan fitur lain agar aplikasi yang dibuat lebih berguna lagi sehingga user lebih suka menggunakan aplikasi yang dibuat.

\section{REFERENCES}

[1] I. G. N. D. P. Yohanes Priyo Atmojo, "Pemanfaatan Augmented Reality Pada Sistem Informasi Geografis Kampus Di Bali,” P. 2, 2014.

[2] S. L. Bagus Putu Wahyu Nirmala," Pemanfaatan Digital Enabler Dalam Transformasi Pemasaran Desa Wisata Berbasis Kerakyatan Di Bali,” P. 3, 2019.

[3] I. G. J. E. P. I. G. P. K. J. I Putu Hendrajaya, Sistem Informasi Geografis Pemetaan Masyarakat Penerima Bantuan Sosial Tepat Sasaran Pada Desa Sulangai Berbasis Web, 2020.

[4] I. G. P. K. J. A. B. P. W. N. Doni Saputra, "Implementasi Sistem Informasi Muselok Menggunakan Augmented Reality Berbasis Android (Studi Kasus Museum Negeri Nusa Tenggara Barat)," 2020.

[5] D. Agustina, "Apa Itu Aplikasi?," 2016. [Online] Available:Https://Jogjaweb.Co.Id/Blog/Apa-ItuAplikasi.

[6] O. D. H. Firdhaus Hari S A H, "Pemanfaatan Augmented Reality Untuk Pengenalan Landmark Pariwisata Kota Surakarta," Teknik Universitas Sahid Surakarta, Surakarta, 2018.

[7] O. D. E. T.M.Zaini, "Promosi Objek Wisata Unggulan Lampung Melalui Media "Magicbook" Berteknologi Augmented Reality," Universitas Lampung, Bandar Lampung, 2014.

[8] Indra Permana, O. D. (n.d.). "Location Based Service Sebagai Penunjuk Lokasi Hotel di Kota Semarang Berbasis Augmented Reality,” 2015. 
e-ISSN: 2685-7006 | p-ISSN: $2252-9063$

Kumpulan Artikel Mahasiswa Pendidikan Teknik Informatika

(KARMAPATI)

Volume 10, Nomor 1, Tahun 2021

\section{KคRMAPATI}

[9] M. P. Y. R. G. Selvia Lorena Br Ginting, "Metode Markerless Untuk Membangun Aplikasi Pemandu Wisata Wilayah Ciayumajakuning Berbasis Mobile Android," Universitas Komputer Indonesia, Pekanbaru, 2017.

[10] E. A. E. Julia Purnama Sari, "Rancang Bangun Aplikasi Layanan Berbasis Lokasi Dengan Penerapan Augmented Reality Menggunakan Metode Markerless Berbasis Android (Studi Kasus: Pencarian Perangkat Daerah Kota Bengkulu)," Universitas Bengkulu, Benkulu, 2014.

[11] E. F. F. C. Abdur Rahman, "Rancang Bangun Aplikasi Informasi Universitas Bengkulu Sebagai Panduan Pengenalan Kampus Menggunakan Metode Markerless Augmented Reality Berbasis Android.," Universitas Bengkulu, Bengkulu, 2014.

[12] F. R. Purba, "Pemanfaatan Sistem Informasi Geografi Dan Augmented Reality Untuk Pembuatan Peta Pariwisata Daerah Istimewa Yogyakarta.," Universitas Gadjah Mada, Yogyakarta, 2016. 